who, hiding under the canopy of human rights activism, would always fail to see justice in the justice of the Islamic legal system, the finality reached in these two cases should have by now allayed whatever apprehension or misgiving they have regarding the reintroduction and implementation of the Islamic penal law as done by the twelve Shari'ah states in the North.

On the whole, and considering the general scope of this book, one cannot but conclude that it is indeed a sourcebook particularly for scholars and research students who are interested in probing further into the historical relevance of the Islamic law in the making of the Nigerian legal system. It will also serve as a useful source of legal information for those who have flair for comparative legal practice in Nigeria. The research value of this treatise regarding the rebirth of the comprehensive Islamic legal system in the Northern states of Nigeria, as of today, remains peerless.

Muhammad-Basheer A. Ismail, Kingston upon Hull

Geo Quinot / Sue Arrowsmith (Eds.)

\title{
Public Procurement Regulations in Africa
}

Cambridge University Press 2013, 445 pages, $£ 85.00$ (US\$ 135.00), ISBN 9781107028326

Public Procurement has long been a neglected area of research. It refers to the process through which the state acquires goods, works and services needed to fulfil its public functions. Regarding the quite significant percentage of GDP that is spent on public procurement, effective and efficient public procurement regulations and their implementation are of particular importance. This has led to the development of a distinct field of legal academic study, however, in Africa public procurement is still a marginal area of research. In African countries the share of GDP used to procure goods, works and services is even higher than in other (developed) countries; it amounts up to $25 \%$ of the GDP. The effectiveness and efficiency of public procurement systems in Africa has, therefore, a decisive impact on socio-economic development.

The book at hand has resulted from a three-year collaboration of the Universities of Nottingham and Stellenbosch under the British Academy's UK-Africa Academic Partnerships scheme. The project's objective has been an analysis of the current state of public procurement regulation in Africa. Quinot and Arrowsmith, two of the leading researchers in the area of public procurement law, have collected nine country studies from Africa, providing doctrinal legal analysis of those countries public procurement systems. The book also includes articles on the role of donors in regard to African procurement systems, procurement methods, supplier remedies, corruption and the promotion of social policy in public procurement in the African context.

The country studies in Part I introduce the public procurement systems by outlining the objectives, nature and organisation as well as the legal regime on public procurement. This is followed by annotations on what procuring entities and which type of procurement are subject to public procurement regulations. Finally, the authors describe and explain the public pro- 
curement methods or procedures applicable within the different systems. Although the country studies only give a very broad overview of the legal regulations and neither analyse shortcomings thereof nor difficulties that arise in implementing the law, the country studies are very important in providing a basis for further research and an introduction to public procurement systems in Africa. Most countries examined have reformed their systems in the past 15 years, often after initiatives and with support from foreign donors or regional organisations. The World Bank, for example, has had an important influence in this respect. Striking is also the direct and indirect influence the 1994 UNCITRAL Model Law on Public Procurement ${ }^{1}$ has had in African countries, only the Namibian and the South African system have no common features with the Model Law. The country studies disclose that some systems are more advanced than others, for example when it comes to review systems, and what elements need to be considered for further reform efforts. Developments such as e-procurement or environmental procurement have not played a significant role in the reform efforts of African governments yet but might be an issue on the agenda in the near future.

Through the country studies becomes obvious what concerns or problems African procurement systems have in common. Articles using a comparative analysis in Part II of the book go into detail with these topics and provide the reader with a comprehensive overview of essential features and critical aspects of public procurement systems in Africa. The use of secondary objectives to promote prior disadvantaged groups is of major importance in African countries which still suffer from the aftermath of colonialism and discrimination. Other key issues are transparency and corruption, suppliers' remedies and the influence of donors on domestic procurement systems. The choice and availability of different procurement methods that match the size, value and type of procurement is another basic but decisive issue for (African) public procurement systems.

The role of donors in the public procurement systems of African countries as major aidrecipients is not limited to pushing for reforms but also concerns the question which public procurement scheme is applied to funded projects. Donors often use their own rules instead of the domestic public procurement regulations despite international efforts to promote the use of national procurement laws. Especially in countries with a reformed and advanced public procurement systems ignorance from the donor's side might be counterproductive for effective implementation of the regulations. Procurement methods in Africa have been strongly influenced by the 1994 UNCITRAL Model Law which basically provides for open tendering, restricted tendering, request for quotations and single-source procurement. Nevertheless, flexible methods for more complex procurements are outlined, too. African countries often make a difference between national and international procurement. Recent developments such as framework agreements or e-procurement have not been introduced by most African countries. The article on supplier's remedies reveals that the close orientation on the UNCITRAL Model Law and the adaption of all provided review mechanisms therein has led to a compre-

1 A revised version of the UNCITRAL Model Law has been issued in 2011 and it remains to be seen whether countries decide to update their systems according to the new Model Law. 
hensive review system which does not always match the resources and capacity available in the countries. The author establishes that a there is a tension between the need for maximal control in regard to a lack of accountability and transparency and the need to optimise procurement in terms of best value for money. The lack of accountability and transparency is closely related to the problem of corruption. What forms corruption can take in public procurement, what possible measures exist and how corruption can be discovered is elaborated in detail in another article. Existing international instruments regarding corruption can also have an impact and are outlined in brief. The importance of social policies in public procurement in Africa makes it a key research topic. The author of the article on this topic stresses the potential of comparative analysis to see how different systems have responded to very similar concerns within their procurement systems. He compares the preferential procurement regulations of South Africa and Kenya and, thereby, provides a good example of using comparative law to identify advantages and shortcomings of social policy approaches in public procurement.

"Public procurement regulation in Africa" provides a comprehensive introduction into sub-Saharan public procurement systems and essential as well as critical public procurement issues from a comparative point of view. Due to the lack of existing research with respect to African legal systems and the importance of public procurement, the book is an excellent starting point for academic research and debate and the promotion of engagement with this significant topic. 